\title{
The Memory of Hesione: Intertextuality and Social Amnesia in Troilus and Cressida
}

\section{Atsuhiko Hirota}

Christophe Hausermann (ed.)

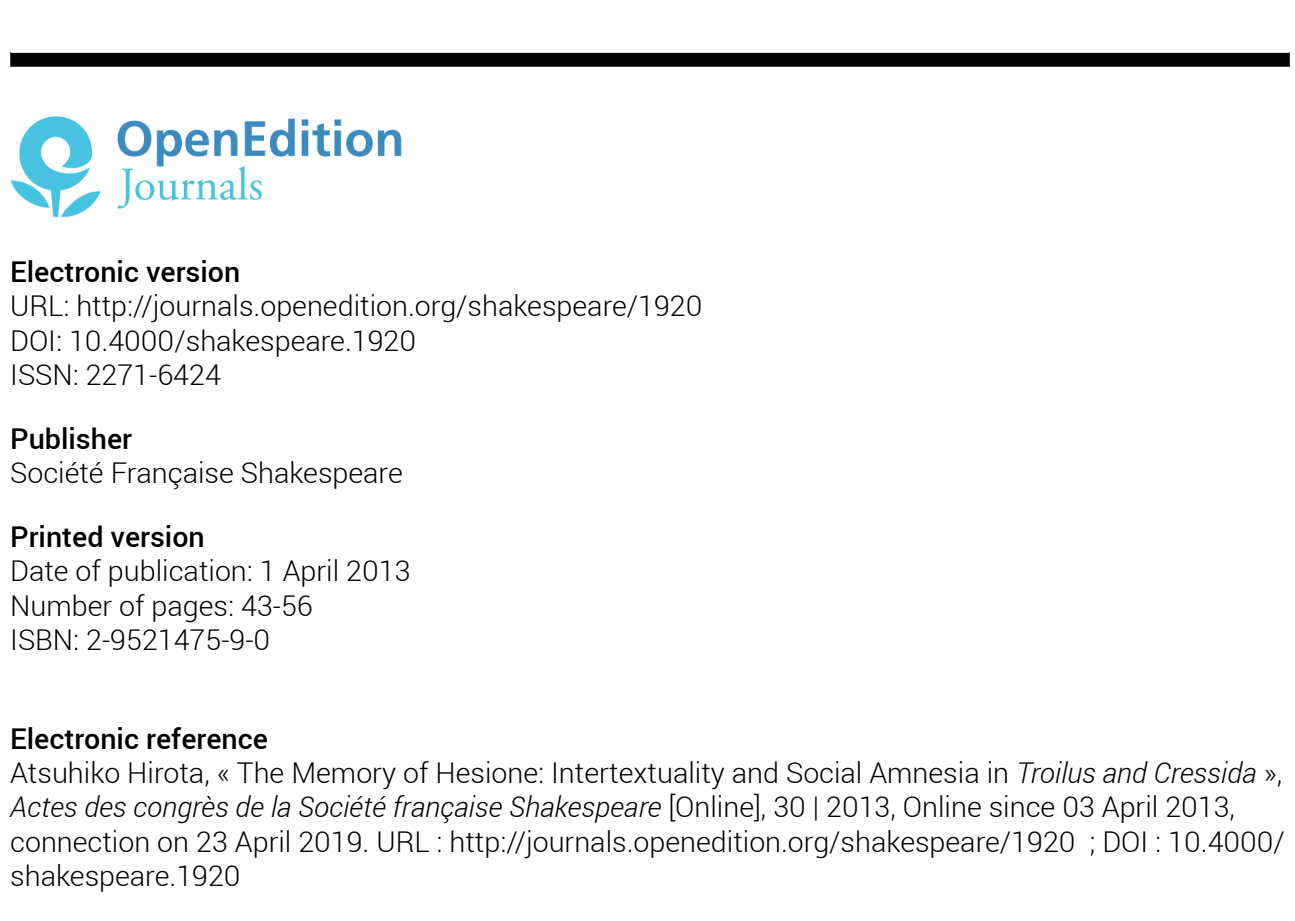




\section{Shakespeare et la mémoire}

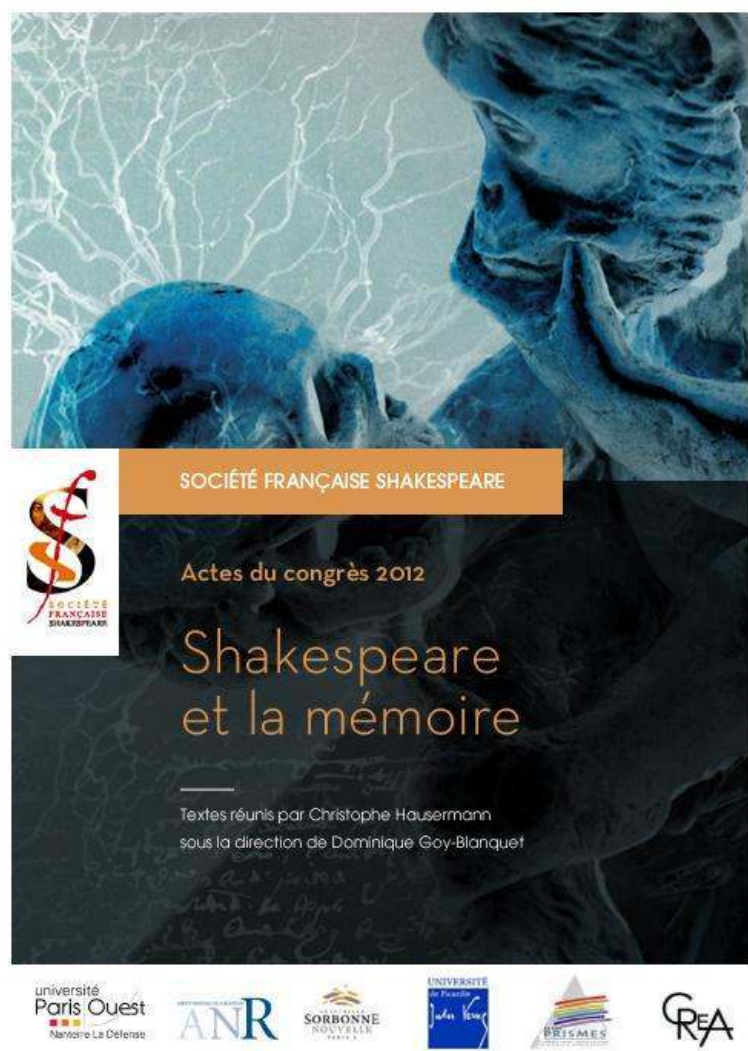

actes du Congrès

organisé par la

SOCIÉTÉ FRANÇAISE SHAKESPEARE

les 22, 23 et 24 mars 2012

textes réunis par

Christophe HAUSERMANN

sous la direction de

Dominique GoY-BLANQUET 


\section{COUVERTURE}

d'après l'affiche de Claire Colombet

conception graphique et logo

Pierre Kapitaniak

mise en page et corrections

Christophe Hausermann

(C) 2012 Société Française Shakespeare

Institut du Monde Anglophone

Université de Paris III - Sorbonne Nouvelle

5 rue de l'École de Médecine 75006 Paris

www.societefrancaiseshakespeare.org

Tous droits de traduction, de reproduction et d'adaptation réservés pour tous les pays 
THE MEMORY OF HESIONE:

InTERTEXTUALity AND Social AMNESia in TROILUS AND CRESSIDA

\begin{abstract}
Atsuhiko Hirota
While the Trojans in Troilus and Cressida are obsessed with the memory of Hesione, the sister of Priam, they suppress her name. The name Hesione is never mentioned throughout the play. This paper argues, with reference to the function of social memory and forgetting, that the rich intertextual associations in this play provide us with a key to understanding this unique characteristic of Shakespeare's play. In the narratives of Ovid, Lydgate and Caxton, the memory of Hesione is inseparable from the destruction of Laomedon's Troy by Hercules. Nestor's reference to Hector's "grandsire" in Troilus and Cressida (I.iii.289) particularly suggests that Shakespeare expected the audience to recall this tale though it is never told in the play. For the Trojans, the memory of Hesione is essential in order to assert their blood-based identity and their righteousness in the ongoing war. Yet, it must not be recalled fully because it also leads to the traumatic history of the previous fall, which may be projected to the future when they are fighting another round of war with the Greeks.
\end{abstract}

Dans Troilus and Cressida, les Troyens sont obsédés par la mémoire d'Hésione, la sœur de Priam, et pourtant son nom n'est jamais directement mentionné dans la pièce. En renvoyant aux processus de mémoire sociale et d'oubli, cet article montre que les nombreuses associations intertextuelles de la pièce fournissent la clé de cette caractéristique tout à fait unique dans le théâtre de Shakespeare. Dans les récits d'Ovide, de Lydgate et de Caxton, la mémoire d'Hésione est toujours liée à la destruction par Hercule de la ville de Troie, gouvernée par Laomédon. L'allusion que Nestor fait à l'aïeul d'Hector dans Troilus and Cressida (1.iii.289) suggère que Shakespeare s'attendait que les spectateurs se souviennent de ce récit, bien qu'il ne soit pas rappelé dans la pièce. Pour les Troyens, la mémoire d'Hésione est primordiale car elle certifie que leur identité repose sur les liens du sang et témoigne de leur bon droit dans le conflit en cours. Cependant, cette mémoire ne saurait être totalement évoquée car elle rappelle du même coup l'histoire traumatisante de la défaite précédente, dont l'ombre pourrait être projetée sur ce nouvel épisode de la guerre contre les Grecs.

$\mathrm{T}$

The Trojans in Troilus and Cressida are obsessed with the memory of Hesione, sister of Priam. However, her name is never mentioned in the course of the play. This absence of Hesione's name is unique to Shakespeare's play as her name frequently appears in classical and medieval texts about the Trojan War, including those which are regarded as Shakespeare's sources. Her name is also mentioned in contemporary and later texts about the Trojan War. In George Chapman's translation of Book 5 of The Iliad ${ }^{1}$, Sarpedon mentions Hesione. Characters in Thomas Heywood's The Iron Age, Part 1- a play printed in 1632 and written, according to David

\footnotetext{
${ }^{1}$ Included in the twelve-book version published c.1609.
} 
Bevington, probably in 1609 or $10^{2}-$ and in John Dryden's postReformation re-configuration of Troilus and Cressida also refer to Hesione by name. In this paper I argue that the rich intertextuality based on the literary tradition about the Trojan-Greek conflict provides us with a key to understanding this peculiarity. This paper is divided in three sections. First of all, I observe that the Trojans' memory of Hesione and the suppression of her name may be regarded as an example of social memory and amnesia. Then I analyse what Shakespeare chose not to dramatize in his play by exploring other texts representing the history of the Trojan War. Finally, I return to Shakespeare's play in order to examine the Greeks' speeches. Nestor's reference to Hector's "grandsire" suggests that Shakespeare expected the audience to recall the tales of Hesione though there is no mention of them in the play.

\section{The Trojans' obsession with Hesione}

The Trojans in Troilus and Cressida recall Hesione in three places in the play: when Cressida's servant Alexander talks about a Greek lord of the Trojan blood (Ajax) (I.ii); in the scene in which Priam and his sons discuss whether they should return Helen to the Greeks and end the war (II.ii); and during the single combat between Hector and Ajax (IV.vii). On the second of these three occasions, Priam reveals to his sons that Nestor has made a proposal that the Greeks will end the war if the Trojans return Helen to them. Hector insists that Helen should be returned but Troilus does not agree and says:

It was thought meet

Paris should do some vengeance on the Greeks.

Your breath of full consent bellied his sails; [...]

And for an old aunt whom the Greeks held captive

He brought a Grecian queen, whose youth and freshness

Wrinkles Apollo's and makes stale the morning.

Why keep we her? The Grecians keep our aunt.

(II.ii.71-79)

According to this argument, Paris' taking of Helen back to Troy therefore the rape of Helen - is justifiable because it was committed in

\footnotetext{
${ }^{2}$ William Shakespeare, Troilus and Cressida, ed. David Bevington, coll. The Arden Shakespeare Third Series. London, Thomson Learning, 1998, p. 394. All subsequent quotations of Troilus and Cressida are taken from the Arden $3^{\text {rd }}$ edition.
} 
retaliation for the Greek taking and keeping of "an old aunt." In this logic, Helen is a hostage to be exchanged against this "old aunt." 3 The contrast between the "old aunt" and "young and the fresh" Helen implies the change of generation - that the Trojans have not forgotten the humiliation inflicted upon the previous generation by the Greeks and also that they won a much better price in return. This speech reveals that there is a longer history not represented in this play.

On the third of the three occasions when Hesione is recalled by the Trojans, Hector says, suspending the single combat with Ajax:

Thou art, great lord, my father's sister's son,

A cousin-german to great Priam's seed.

The obligation of our blood forbids

A gory emulation 'twixt us twain.

(IV.vii.4-7)

Here, Hector insists that their kinship forbids him to fight Ajax. Hector says if the Trojan and Greek bloods had been separated in each of Ajax's limbs, he would not have left the Greek ones unwounded (8-16), but Ajax's Trojan blood blurs the Trojan/Greek distinction and suspends the combat. Hector also says:

But the just gods gainsay

That any drop thou borrowed'st from thy mother,

My sacred aunt, should by my mortal sword

Be drained.

(IV.vii.16-19)

His recalling of Hesione is combined with the obsession with blood. For him, Trojan blood defines Trojan identity. Like his brother Troilus, Hector also refers to his aunt without naming her. These Trojans persist in regarding Hesione as a member of the royal family though her son is among the Greeks during the siege of Troy. 4

\footnotetext{
3 Bevington notes that Troilus' reference to Hesione is likely to have a bawdy connotation especially because Hesione the "aunt" is here paired with "queen" Helen through a pun on "quean" (ibid. p. 361). In this context, even Hector's consecration of Hesione by calling her his "sacred aunt" (IV.vii.7.18) carries an ironical and bawdy implication because the term "aunt" was used in the sense of "A whore; a wanton; a paramour "not of lofty origin, nor of good social standing”' (Eric Partridge, Shakespeare’s Bawdy, Third ed., 1968, rpt., London and New York, Routledge, 1990, p. 60). The OED (aunt 3) gives an obsolete meaning, "A bawd or procuress; a prostitute" and gives a quotation from Thomas Middleton's Michaelmas Term (1607) as the first example.

4 In Dryden's Troilus and Cressida, Hector says to Ajax during their encounter: "Ajax, thou art my Aunt Hesione's Son; / The obligation of our blood forbids us," calling Hesione by her name (John Dryden, Troilus and Cressida or, Truth Found Too Late, in Alan Roper, gen. ed., The Works of John Dryden, vol. 13, ed. Maximillian E. Novak, Berkeley, University of California Press, 1984, IV.ii.89-90).
} 
Before these two scenes, Shakespeare draws the audience's attention to Hesione for the first time through the recollection of her nephews. Alexander, a servant of Cressida, says to his mistress: "The noise goes, this: there is among the Greeks / A lord of Trojan blood, nephew to Hector; / They call him Ajax" (I.ii.12-14). This speech is remarkable in several respects. First, this "noise" (that is, a rumour) is not accurate. Ajax is in truth Hector's cousin. 5 This inaccuracy may suggest the distance between the royal family and the commoners. The Trojan servants, including Alexander, may not have an accurate knowledge of the relationship among the royal families. Yet this "noise" reveals that Ajax's Trojan origins through his mother are well-known among the commoners. Also, unlike the other two speeches we quoted, this one is spoken by a Trojan commoner, not by the members of the royal family of Troy closely linked by blood and by marriage (like Aeneas, whose wife Creusa is one of Priam's daughters). This is all the more remarkable, as later in this scene Pandarus calls the common soldiers of Troy "Asses, fools, dolts; chaff and bran, chaff and bran; porridge after meat" (238-39) and disdainfully emphasizes the distinction between the royal family and the commoners. ${ }^{6}$ The memory of Hesione is retained not only among her relatives. Alexander's reference to Ajax as a "nephew to Hector" reveals that the memory of Hesione is part of the collective memory of most of the Trojans. In this sense, this memory may be called "social."

In an article entitled "History as Social Memory," Peter Burke summarizes Maurice Halbwachs' argument that "memories are constructed by social groups" and writes, "It is individuals who remember, in the literal, physical sense, but it is social groups who determine what is 'memorable' and also how it will be remembered."7 As memory is plastic, it is closely related to forgetting, or suppression of memory. More recently, Garret J. Sullivan wrote about the functions of social memory and forgetting in the construction of subjectivity in English Renaissance drama, "Remembering is [...] an action or set of actions that arises out of the subject's response to specific social

\footnotetext{
5 The term "nephew" does not mean "cousin" according to the $O E D$.

6 Although Peter Hyland points out that it is as if "the Greeks are all kings and the Trojans are all members of royal family" (Peter Hyland, "Legitimacy in Interpretation: The Bastard Voice in Troilus and Cressida," Mosaic 26.1, Winter 1993, p. 6), Troilus and Cressida thus records the voices of the Trojan plebians.

7 Peter Burke, Varieties of Cultural History, Cambridge, Polity Press, 1997, p. 44.
} 
circumstances and a particular imperative to remember (that is, the imperative to behave in a certain way)." 8 The Trojans remember Hesione but do not refer to her by name. The three examples we have seen reveal that the Trojans' memory of her is social. If, as Sullivan argues, this memory is a response to specific social circumstances, the ongoing war should be the imperative to recall this particular memory. Hesione is recalled as the Trojans need to assert their righteousness in the Trojan War (as Troilus' speech reveals) and to confirm their bloodbased identity (as Hector's suggests). Likewise, the exclusion of her name from this memory is collective and may be a case of "social amnesia" "the term used by Burke to signify the "social organization of forgetting, the rules of exclusion, suppression or repression, and the question of who wants whom to forget what, and why"). ${ }^{9}$ Then, why do the Trojans obsessively recall her and yet exclude her name from their speech? In order to seek the reason for this ambivalence, I next explore the narratives describing the Trojan-Greek relationship before the war.

\section{The tales of Hesione}

The tale of Hesione being taken to Greece is part of the legend of Troy and repeatedly narrated in classical and medieval texts. The details vary, but the basic narrative stresses the greed and ingratitude of King Laomedon of Troy, the father of Priam and Hesione, and the destruction of Troy as a due result. According to Book 11 of Ovid's Metamorphoses, Apollo and Neptune help Laomedon to build the walls of Troy but as Laomedon refuses to pay the promised wages to the gods, Neptune floods the fields and sends a monster to carry off his daughter. Hesione is bound to a rock until Hercules comes and rescues her in exchange for a reward of Laomedon's horses. When Laomedon again refuses to give the promised reward, Hercules destroys Troy and gives Hesione to Telamon, "in honour of his service" (line 241),

\footnotetext{
${ }^{8}$ Garrett A. Sullivan, Memory and Forgetting in English Renaissance Drama: Shakespeare, Marlowe, Webster, Cambridge, Cambridge University Press, 2005, p. 11. Sullivan defines "remembering" as "action taken in response to a call to behave in a certain (more or less precisely defined) fashion" (ibid. p. 9). For the significance of social memory (and forgetting) in Shakespeare's plays, see Anthony Dawson, "The Arithmetic of Memory: Shakespeare's Theatre and the National Past," Shakespeare Survey 52, 1999, p. 54-67, especially p. 55 and p. 61-62.

9 Burke, op. cit,. p. 56-57.
} 
according to Arthur Golding's translation. ${ }^{10}$ Golding summarizes this narrative in a gloss as "The ingratitude of Troy." The falsehood of Laomedon is expressed as if the king's sin expanded to Troy as a whole, by such phrases as "covetous Troy" (233) and the "twice-forsworn false town of Troy" (241). Also, the term "false" is used repeatedly with reference to Laomedon in lines 230 ("And falsely faced them [the gods] down with oaths it was not as they said") and 235-36 ("And, thinking this too small / A penance for the falsehood..."). ${ }^{11}$

George Chapman mentions the tale of Hesione in his translation of The Iliad. Sarpedon, Zeus' son by Laodameia and the king of Lycia, says to Tlepolemus, Hercules' son, when they meet in the battlefield:

Thy father, holy Ilion, in that sort ouer-threw;

Th'iniustice of the king was cause, that where thy father had

Vsde good deseruings to his state, he quitted him with bad.

Hesione, the ioy and grace of king Laomedon,

Thy father rescu'd from a whale, and gaue to Telamon

In honourd Nupt[i]alls. Telamon, from whom your strongest Greeke

Boasts to haue issude; and this grace might well expect the like:

Yet he gaue taunts for thanks, and kept against his oath, his horse;

And therefore both thy fathers strength, and Iustice might enforce

The wreake hee tooke on Troy.

$(\mathrm{M} 3 \mathrm{r})^{12}$

Here Sarpedon repeats the tale described in The Metamorphoses narrating how Hercules destroyed Laomedon's Troy in retaliation for the king's not rewarding him with the promised horses for rescuing Hesione from the sea-monster. Hence the emphasis on Laomedon's injustice and the fall of his Troy. It is noteworthy that Hesione is not mentioned in this speech in the versions usually read today. In A. T. Murray's translation in the Loeb Classical Library, for example, Sarpedon says in the corresponding lines, "Tlepolemus, it is true your sire destroyed sacred Ilios through the folly of that lordly man, Laomedon, who rebuked with harsh words him that had done him

${ }^{10}$ Madeleine Forey, ed, Ovid's Metamorphoses: Translated by Arthur Golding, Baltimore, The Johns Hopkins University Press, 2002. All quotations from Golding's translation of The Metamorphoses are taken from this edition.

11 Natale Conti's Mythologiae (first published in 1567) describes Neptune's building of Troy's walls with Apollo, Laomedon's neglect of Neptune's work, angry Neptune's sending of a sea-monster, and the oracle to sacrifice Hesione in the chapter "On Neptune." It also records Herodotus' denial of the whole episode (John Mulryan and Steven Brown, trans. Natale Conti's Mythologiae, Tempe, Arizona, ACMRS [Arizona Center for Medieval and Renaissance Studies], 2006, p. 142-44).

12 George Chapman, Homer Prince of Poets: translated According to the Greeke, in Twelue Bookes of his Iliads..., London, c.1609, STC 13633. 
good service, and did not give him the mares for whose sake he had come from afar." ${ }^{3}$ Chapman gives a full version of the destruction of Laomedon's Troy by Hercules as described in The Metamorphoses. From Chapman's version, we can see that the early modern Englishmen were familiar with the tale of Hesione - it was immediately recalled when the destruction of Laomedon's Troy by Hercules was mentioned, together with the ingratitude of Laomedon.

John Lydgate's Troy Book, one of the fifteenth-century narratives on the Trojan War (written in c. 1412 to 20), narrates a different story of the fall of Laomedon's Troy and the abduction of Hesione by Hercules. In this version, Hercules attacks Troy with his Greek companions including Nestor, Jason and Theseus after the voyage of the Argonauts in retaliation for Laomedon's inhospitality on their way to Colchis. William Caxton's The Recuyell of the Historyes of Troye (translated from Raoul Lefèvre's Recueil des Histoires de Troie around 1471-75) narrates both tales. ${ }^{14}$ As a result, The Recuyell records the repeated fall of Laomedon's Troy at the hands of Hercules: once after the killing of the sea-monster (as written in The Metamorphoses) from which Laomedon "fled away preuely" with his daughters Hesione and Antigone, ${ }^{15}$ and then after the voyage of the Argonauts (as in Lydgate) in which Laomedon is killed and Hesione is taken prisoner. ${ }^{16}$

13 Homer, Iliad, books 1-12, Translated by A. T. Murray and revised by William F. Wyatt, coll. Loeb Classical Library, Cambridge, Mass., Harvard University Press 1999, p. 255. There is no reference to Hesione in Robert Fagles's translation, either (Homer, The Iliad, 1990, Harmondwsworth, Penguin Books, 1991, 5.743-52).

14 Caxton's narrative of the first fall is not completely identical with Ovid's. For example, while in The Metamorphoses the gods assume the shape of men and negotiate with Laomedon for the reward (11.226-28 in Golding's translation), Caxton writes, "[Laomedon] wente vnto the temple of the god of the sonne \& of the see That were passing riche And took all the money that he cowed finde / promettyng to paye hit agayn at a certayn day \& tyme sette" (H. Oskar Sommer, ed., The Recuyell of the Historyes of Troye: Written in French by Raoul Lefevre, Translated and Printed by William Caxton (About A.D. 1474), vols. I \& II, 1894, rpt., New York, AMS Press, 1973, p. 271). Also, the gods firstly send the flood and ardent sunshine which cause pestilence in Caxton but not in The Metamorphoses. 15 Caxton, op. cit. p. 295.

16 In The Merchant of Venice (The Oxford Shakespeare: The Complete Works, ed. Gary Taylor, Oxford, O.U.P., 2005), Portia's speech in the scene of Bassanio's choice of caskets reveals that Shakespeare was familiar with the tale recorded in The Metamorphoses and The Recuyell. Portia says: 
Both Lydgate and Caxton give the following tale as the later history of Troy. Priam (who was absent from Troy at the time of Laomedon's death and Hesione's abduction) rebuilds Troy and sends Antenor to Greece for the negotiation to have Hesione back. The Greek kings, including Telamon and Nestor, disdainfully refuse the request. Then, after asking for advice from the Trojans including his sons, Priam sends Paris to Greece in order to bring back a Greek woman so that Hesione may be returned in exchange for her, with the abduction of Helen as the result.

Thomas Heywood's The Iron Age, Part 1 follows these fifteenthcentury narratives. It begins with Priam's speech to the Trojans:

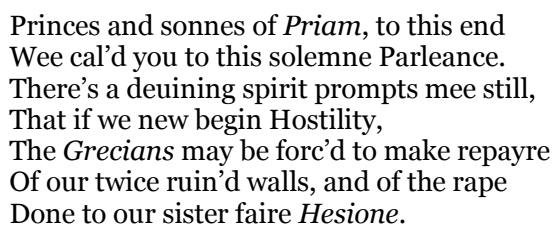

The Trojans' counsel in this opening scene is focused on how they may retaliate against the Greeks for the repeated fall of Troy and the "rape of Hesione." The sons of Priam recall the history. Paris says, "What iuster cause / When the whole world takes note to our disgrace, / Of this our Troy, twice rac't by Hercules" and Troilus adds, "And faire Hesione rapt hence to Greece, / Where she still liues coopt vp in Salamine", i.e. Salamis, of which Telamon is the chieftain (266). Then Hector gives a more detailed account of the destruction of Troy by Hercules. He begins his speech with a recollection of the repeated destruction, saying, "Troy was twice rac't, and Troy deseru'd that wracke." He continues that Hercules saved Hesione from the seamonster, that Laomedon ungratefully refused the reward he had

With blearèd visages come forth to view The issue of th'exploit. Go, Hercules.

(3.2.53-60)

Here Portia compares herself to Hesione being bound to a rock and waiting for HerculesBassanio's rescue. At the same time, this comparison draws a parallel between her deceased father and the false Laomedon, who is to be killed by her rescuer, which suggests Portia's frustration with her father.

17 The Dramatic Works of Thomas Heywood Now First Collected with Illustrative Notes and a Memoir of the Author in Six Volumes, Vol. 3, 1874, rpt., New York, Russell \& Russell Inc., 1964. All quotations from The Iron Age, Part 1 are taken from this edition. As this edition does not give line numbers, I refer to page numbers for each quotation. 
promised, and that "Troy therefore drew iust ruine on it selfe." Hector also insists on the fact that Hesione's abduction was a just cause:

Tis true, our Aunt was borne away to Greece.

Who with more iustice might transport her hence,

Then he whose prise she was? Bold Telamon

For ventring first vpon the wals of Troy,

Alcides gaue her to the Salmine Duke.

Until he hears the report of Antenor, who just returns from Greece, Hector is the only opponent to the Trojans' plan for retaliation. Antenor says:

Newes of dishonour to the name of Priam,

Your Highnesse Sister faire Hesione:

Esteem'd there as a strumpet, and no Queene;

[...] neuer was Princesse

So basely vs'd.

Like Caxton and Lydgate, Heywood mentions that Telamon does not properly marry Hesione. The term "strumpet," which Antenor uses to refer to Hesione, reveals a status even worse than that of a concubine as she is usually regarded to be in Salamis. Hearing this, the Trojans, including Hector, unanimously decide to send Paris to Greece. Thus, in these earlier texts on the Trojan War as well as in a contemporary play, the abduction and ill-treatment of Hesione by the Greeks is represented and featured as the origin of the rape of Helen although Shakespeare does not repeat this tale in his play.

\section{Nestor's recollections}

The Greeks in Troilus and Cressida are generally indifferent to the history before the rape of Helen by Paris. We find one example of their indifference in a dialogue between Aeneas and Achilles. Aeneas says:

This Ajax is half made of Hector's blood,

In love whereof half Hector stays at home.

Half heart, half hand, half Hector comes to seek

This blended knight, half Trojan and half Greek.

$(4.6 .85-88)$

To this speech Achilles only replies, "A maiden battle, then? O, I perceive you" (89) and shows no interest in Ajax's Trojan, or Greek, blood although he is another first cousin (or "cousin-german") of 
Ajax. ${ }^{18}$ This indifference may be attributed to the characterization of Achilles in this play but it also suggests that the memory of Hesione is not particularly important to the Greeks. Burke observes, "[the victors] can afford to forget." 19 The Greek indifference to Hesione is another example of social amnesia.

Nestor is the only character in the Greek camp who recollects the events of the past. In Act 1 scene 3, he says to Aeneas, after listening to Hector's challenge to the Greeks, "Tell him of Nestor, one that was a man / When Hector's grandsire sucked" (288-89). Later, after Hector suspends the single combat with Ajax, Nestor also says, this time to Hector himself:

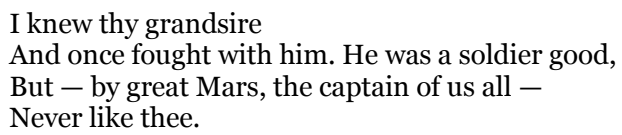

Hearing this speech, Hector calls Nestor "good old chronicle" (86), referring to his memory. ${ }^{20}$ The combat between Nestor and Laomedon is not in Caxton's Recuyell, but Book 1 of Lydgate's Troy Book gives an extensive narrative of it for over fifty lines (4147-98). ${ }^{21}$ In Lydgate, Nestor gives a wound to Laomedon (4163) and unhorses him (4168). They then fight on foot (4182-90) and Laomedon is about to kill Nestor when the Greeks come to rescue him. Lydgate's description of Hercules' killing of Laomedon runs as follows:

\footnotetext{
18 Achilles' father Peleus and Ajax's father Telamon are brothers. It is unlikely that Shakespeare was ignorant of this kinship because in The Metamorphoses the tale of Peleus' conquest of Thetis by the will of Jove, which results in the birth of Achilles, immediately follows that of Telamon's receipt of Hesione (see Book 11, 242-302 in Golding's translation). Kenneth Palmer points this out in the footnote to IV.v.119 in his edition of Troilus and Cressida and comments, that it is "a passage Shakespeare certainly knew" (William Shakespeare, Troilus and Cressida, ed. Kenneth Palmer, coll. the Arden Shakespeare Second Series, 1982, rpt., London and New York, Routledge, 1990, p. 251).

19 Burke, op. cit., p. 54 .

20 This image of Nestor as a chronicle may well refer to the old Greek's verbosity.

${ }^{21}$ Quotations from Lydgate's Troy Book are taken from Henry Bergen, ed., Lydgate's Troy Book, Part 1, coll. The Early English Text Society, Extra Series 97, London, Kegan Paul, Trench, Trübner \& Co., Ltd., 1906. Caxton merely cites Nestor's name among those who assaulted Troy with Hercules, "Iason was at that tyme in a fer strange contre. Hercules had with hym many noble men And amonge all other ther were with hym the kynge thelamomax the duc Nestor. Castor. pollux. theseus and many kynges and dukes" (Caxton, op. cit., p. 349).
} 
And with a swerde, scharp[e] grounde \& whet,

Smot of his hede, per was noon oper grace,

And caste it furthe in be silue place

Among be hors, by cruel violence,

With-oute pite and any reuerence.

$(4306-10)^{22}$

Lydgate next describes the Greeks taking the Trojan maidens as spoils (4337-4340), and Hercules giving Hesione (Exione) to Telamon (Thelamoun) as the reward for entering Troy first of all (4347-50). Then follows the narrative on Telamon's improper treatment of Hesione as a concubine (4351-72). ${ }^{23}$ Shakespeare's Nestor does not mention the name Laomedon, nor Hesione. Yet, his reference to the "grandsire" of Hector makes those who are familiar with the tale of the fall of Laomedon's Troy recall that the characters in Troilus and Cressida are not free from the events of the past.

\section{Conclusion}

Helen is at the centre of the Trojan War because all the bloodshedg is caused by Paris' rape. This centre, however, is empty in the sense that both sides are aware that she is not worth the massive bloodshed this war inflicts upon them. The cynicism permeating Troilus and Cressida is partly caused by this awareness. The Trojans take Paris' rape of Helen as their just retaliation for the Greek rape of Hesione. For them, Hesione is the true cause of the war as it is seen as a case of the "traffic of women" preceding that of Helen. ${ }^{24}$ Hesione is even more shadowy than Helen: she does not appear on stage and her name is never spoken. Her absence, however, reminds the spectators who are familiar with the tales of Troy and the literary tradition about the conflict

\footnotetext{
22 Caxton narrates the death of Laomedon vividly and somewhat grotesquely:

And fyndyng there laomedon that dide there mervaylles of armes vpon the grekes / he [Hercules] smote hym wyth his clubbe often tymes vpon his helme in suche wyse that he myght not saue hym / And that he enbarryd his clubbe with in his heed and brayn / that with the strook he slewe hym amonge plente of grekes lyng ded on the sand eendyng there the ende of hys lyf. (ibid., p. 350).

23 The slaying of Laomedon by Hercules and the destiny of Hesione after the fall of Troy are also described in Caxton. Caxton writes, "[...] they entrid in to ylion and pullyd hit / and after did do Crye hauok vpon all the tresours of troyes. In like wise they toke Exiona the doughter of the kynge. whom hercules gaf vnto thelamon requyryng hym to take her for as moche as he was the firste that entrid the Cyte" (ibid., p. 351).

24 For the phrase "traffic of women," see Marilyn Desmond, Reading Dido: Gender, Textuality, and the Medieval Aeneid, Minneapolis and London, University of Minnesota Press, 1994, p. 26
} 
between the Trojans and the Greeks underlying the world of this play, that she embodies the humiliation the Trojans have experienced. The memory of Hesione in this play relies on the audiences' memory of the Trojan War literature.

The memory of Hesione also suggests what the Trojans want to remember and to forget, through the function of social memory and amnesia conditioned by the circumstantial imperative. They need to recall her fate in order to justify their position in the ongoing war. Yet it must not be recalled fully because it also leads to the traumatic history of the previous fall, which may easily be projected in the future, especially when they are fighting another round of war with the Greeks. We know that Shakespeare was sensitive to the issue of what was to be left un-mentioned in history. In the opening scene of Henry IV, Part 1 the Earl of Westmoreland talks to the king about the abuse of the bodies of dead English soldiers by Welshwomen and says, "Such beastly shameless transformation, / By those Welshwomen done as may not be / Without much shame retold or spoken of" (I.i.44-46). The details of the abuse are never specified in this play although Holinshed's Chronicles gives vivid accounts of them. ${ }^{25}$ For the Trojans the humiliation of the previous generation - the fall (or, even worse, repeated fall) of Laomedon's Troy, his death at the hands of Hercules, and the taking of Hesione to Greece to be given to Telamon as a concubine (or a strumpet) - may not be retold or spoken of without much shame, especially as it originates in Laomedon's ingratitude, falsehood, and inhospitality.

\footnotetext{
25 The second edition of the Chronicles - the edition which is generally regarded as one of the main sources of 1 Henry $I V$ - records this defeat in two places. The first follows the description of Mortimer's capture and runs as following, "The shamefull villanie vsed by the Welshwomen towards the dead carcasses, was such, as honest eares would be ashamed to heare, and continent toongs to speake thereof" (Raphael Holinshed, Holinshed's Chronicles of England, Scotland and Ireland, Vol. 3, New York, AMS Press, Inc., 1965, p. 20). Here this abominable deed is characterized by phrases such as "shamefull villanie" and "ashamed to heare [...] and speake." Westmoreland's reluctance to tell details apparently derives from this speech. Later, however, the Chronicles gives details of this "shamefull villanie." After recording the defeat of the Welshmen resulting in the capture of Glendower's son and his "chancellor," the Chronicles describes the Welshwomen's atrocity in the previous battle in which Mortimer was taken prisoner, "the women of Wales cut off their priuities, and put one part thereof into the mouthes of euerie dead man, in such sort that the cullions hoong downe to their chins; and not so contented, they did cut off their noses and thrust them into their tailes as they laie on the ground mangled and defaced" (ibid., p. 34).
} 
By representing the memory of Hesione in this distinctive way, Shakespeare manages to dramatize the Trojan's ambivalence towards their own history.

Atsuhiko Hirota

Kyoto University 